\title{
Guarantees used in refundable financing of innovation in micro, small and medium-sized enterprises
} The regional bank for the development of the extreme South Inova program

\author{
Richard Cunha Schmidt \\ Banco Regional de Desenvolvimento do Extremo Sul - BRDE, \\ Florianopolis, Brazil, and \\ Micheline Gaia Hoffmann \\ Centro de Ciências da Administração e Socioeconômicas - ESAG, \\ Universidade do Estado de Santa Catarina, \\ Florianopolis, Brazil
}

\begin{abstract}
Purpose - Despite the increasing availability of financing programs for innovation, micro, small and medium-sized enterprises (MSMEs) often find it difficult to access credit for their projects. Among the reasons, the lack of the types of guarantees required by financial institutions stands out. Focused on this problem, in 2013, the Regional Bank for the Development of the Extreme South (BRDE) created a policy to stimulate innovation, making the required guarantees for financing operations of innovative companies more flexible: the BRDE Inova Program. This paper aims to analyze the guarantees used in the bank operations since the beginning of the program.
\end{abstract}

Design/methodology/approach - In the first stage of the research, the authors identified the guarantees used in each of the signed contracts, through a documentary survey. Next, semi-structured interviews showed the perceptions of the players involved in the innovation ecosystem of the state of Santa Catarina, regarding aspects related to the guarantees. Specifically, the authors investigated the following elements: strengths and limitations of the programs regarding access to credit for innovation; adequacy of existing guarantee mechanisms. To strengthen the conclusions, they used triangulated data collection in different stages.

Findings - The results showed that, on the one hand, the initiative helped BRDE to consolidate itself as the main financing agent of innovation in MSMEs; on the other hand, the need for traditional guarantees still plays a significant role for innovative MSMEs to access credit.

(C) Richard Cunha Schmidt and Micheline Gaia Hoffmann. Published in Innovation \& Management Review. Published by Emerald Publishing Limited. This article is published under the Creative Commons Attribution (CC BY 4.0) licence. Anyone may reproduce, distribute, translate and create derivative works of this article (for both commercial and non-commercial purposes), subject to full attribution to the original publication and authors. The full terms of this licence may be seen at http:// creativecommons.org/licences/by/4.0/legalcode

The authors wish to thank the Santa Catarina Research Foundation (FAPESC) for the resources received to carry out this research.
Guarantees used in refundable financing
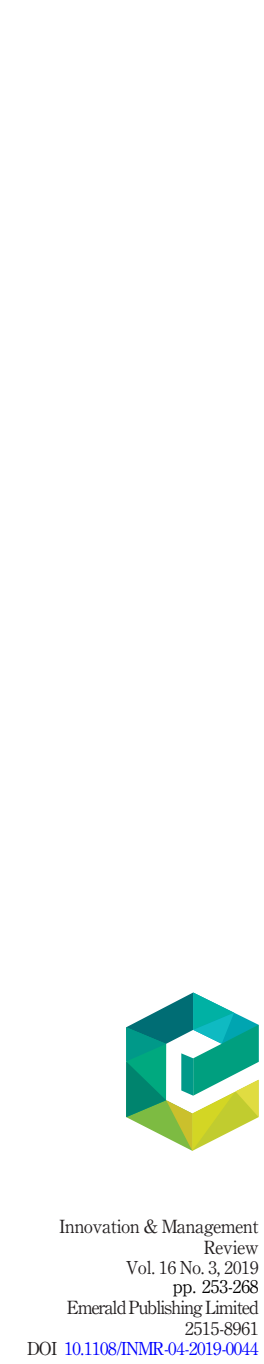
INMR 16,3

Originality/value - In addition to practical implications for the bank and other financing agents' policies, this paper contributes to fill a gap in the literature on guarantee systems applied to the specificities of knowledge-intensive MSMEs.

Keywords Refundable financing, Guarantees, Innovation, MSME

Paper type Research paper

\section{4}

\section{Introduction}

Innovation is a phenomenon of increasing importance in contemporary organizations and society; it is associated with productivity growth (OECD, 2005), competitiveness (Borges \& Hoffmann, 2017; Zen \& Fracasso, 2012), and the development of nations (Schumpeter, 1982). However, companies' own resources are insufficient to support their investments in innovation (Corder \& Salles Filho, 2009; OECD, 2005). Therefore, they need other financing sources to make new projects feasible, and the entrepreneur needs credit to make new combinations in the means of production (Schumpeter, 1982).

In a scenario of economic and fiscal crisis, where resources are scarcer, refundable credit from development banks, under specific conditions for the needs of innovative firms, is an alternative for stimulating innovation in companies and an instrument of anti-cyclical economic policy. Although the federal government provides specific reimbursable financing programs for innovation investments, micro, small and medium-sized enterprises (MSMEs) face serious difficulties to access these resources. Among other reasons, the lack of guarantees required by financial institutions to fund MSMEs operations is very relevant because investment in fixed assets tends to be relatively smaller (Luo, Wang, \& Yang, 2016; Nicolae \& Daniel, 2011; Zica \& Martins, 2008). Although technology is one of the most determinant assets of companies' success, usually it is not accepted as collateral due to the difficulty in estimating the monetary value of intangible assets (Jang \& Chang, 2008).

Although there are different initiatives in the world to circumvent the problem, each instrument has its own limitations. Particularly in developing countries, these mechanisms are not always available or are at an early stage. Given this scenario, the Regional Bank for the Development of the Extreme South (BRDE) created the BRDE Inova Program in 2013, which enables a greater flexibility compared to the guarantees conventionally required in the financing of innovative projects. Almost all resources passed on by BRDE come from the National Bank for Economic and Social Development (BNDES) and the Funding Agency for Innovation and Research (Finep). BRDE Inova has essentially used funds from the programs "Finep Inovacred" and "BNDES Innovative MSME."

From an academic perspective, the impact of credit guarantees, especially for MSMEs, is a topic that has received increasing attention (Nicolae \& Daniel, 2011). In the systematic review of the literature, carried out in the preliminary stage of this research, we found that, on one side, there are a growing number of publications related to credit, guarantees and innovation, or to MSMEs; on the other hand, there are few studies on specific guarantee schemes for innovative or technological companies or sectors. Of the 22 papers that resulted from the systematic review, four were published in the 1990s, five between 2000 and 2009, and the remaining 13 papers between 2010 and February 2016. Only one of the articles dealt specifically with guarantee schemes and funding to knowledge-intensive companies (Jang \& Chang, 2008), while most of them addressed guarantee systems for MSMEs financing.

Therefore, we propose the following research question: How does the guarantee system adopted by "BRDE Inova" meet the requirements of knowledge-intensive MSMEs, regarding their credit needs for innovation? To answer this question, this article examined 
the appropriateness of the guarantees used in the refundable financing operations of the "BRDE Inova" program to the needs of knowledge-intensive MSMEs.

For this purpose, in a first stage, we surveyed all operations that used funds from the programs Inovacred and Innovative MSMEs, since the creation of BRDE Inova. The purpose was to classify and analyze the guarantees that enabled these companies to get credit for innovation. By examining each of the contracted projects, our research offers an additional contribution compared to studies that focused their analyses at the programs' level. Next, we sought to identify how players of the innovation ecosystem of the state of Santa Catarina, who have used these programs, see the access of knowledge-intensive MSMEs to innovation financing, especially regarding the required guarantees. From the documentary survey and the interviews conducted herein, we present a triangulated data research to provide better support for the analysis.

\section{The guarantees' issue regarding credit for innovation in micro, small and medium-sized enterprises}

MSMEs are one of the main sources of innovation, productivity and economic growth (OECD, 2006). They are the engine of the world economy, providing a large number of jobs, creating entrepreneurial spirit and technical innovation (Luo et al., 2016). However, they face barriers stemming from the high costs of innovation activities, the shortage of appropriate sources of financing and excessive economic risks. For these companies, equity is the main source of funding for innovative activities (IBGE, 2013). However, they lack resources to carry out innovation projects and face more troubles in getting external funding than larger firms, which hinders their investments in innovation (OECD, 2005) and reduces the country's ability to create virtuous circles of growth and development (Corder \& Salles Filho, 2009).

There are many reasons for credit restriction faced by MSMEs, and among them the lack of guarantees (Nicolae \& Daniel, 2011; Zica \& Martins, 2008), information asymmetry (Luo et al., 2016; Zica \& Martins, 2008), and the relatively higher cost of operations (Baumgartner \& Casarotto Filho, 2001; Santos, 2006) stand out. A survey on credit in the state of São Paulo shows that 61 per cent of the formal MSMEs do not have access to credit, and 40 per cent of the companies mentioned the shortage of guarantees as the main inhibitor to financing (Sebrae-SP, 2006). Even in developed countries such as Australia, the scarcity of guarantees is a significant problem for accessing credit (Sabatini-Marques, Yigitcanlar, \& Costa, 2015), which hinders the achievement of financing, although resources are available and financial institutions are interested in these operations (Baumgartner \& Casarotto Filho, 2001). Guarantees are disciplinary mechanisms that encourage less risky behaviors, and have the role of mitigating risks arising from information asymmetry, which, especially in the case of MSMEs, add to the shortage and low quality of information. Their absence increases risk perception by financial agents (Santos, 2006). Guarantees constitute a higher personal and asset commitment from the borrower (Baumgartner \& Casarotto Filho, 2001).

The basic (or traditional) guarantees used in long-term financing are the real guarantees and the personal or fidejussory guarantees (Borges, 1999; Casagrande, 2001). The real guarantees consist of the delivery or offer of movables, real estate, livestock or credit rights (Casagrande, 2001), i.e. they focus on specific assets or things (Borges, 1999) and not on the debtor's freedom (Borges, 1999; Zica \& Martins, 2008). The most used ones are mortgage, fiduciary alienation and pledge (Borges, 1999). In addition, there are other types of real guarantees, such as the assignment of claims as collateral (Casagrande, 2001; Fortuna, 2008) and the antichresis (Casagrande, 2001). 
INMR

16,3

Fidejussory or personal guarantees are those given by individuals or legal entities that assume the obligation to honor a particular financial commitment, in case of default of the main debtor (Araújo, 2014). In this case, the guarantor's assets ensure the debt payment (Casagrande, 2001). The endorsement and the guarantee are among fidejussory guarantees (Borges, 1999; Casagrande, 2001).

\subsection{Specificities of knowledge-intensive micro, small and medium-sized enterprises}

The problem of access to credit guarantees is bigger in knowledge-intensive or technologyintensive companies (Associação Brasileira das Empresas de Software, 2016; GarciaTabuenca \& Crespo-Espert, 2010). This should be carefully taken into consideration in public policies that stimulate Science, Technology and Innovation (ST\&I), given the relevance of these companies for a country's technological development. Buainain, Lima and Corder (2017) emphasize the importance, particularly in Brazil, of funding mechanisms to consider the specificities of knowledge-intensive sectors, critical for changing the characteristics of the country's production structure, still dominated by competitive sectors based on resources and scale. For these authors, the proposition of national policies to change this structure did not succeed, partly because of the inadequacy of the financing instruments.

Regarding the adequacy of the main real basic guarantees, on the one hand, mortgage has the advantage of enforcing the whole set represented by the production unit's property (Borges, 1999); fiduciary alienation has a fast process of guarantee enforcement (Fortuna, 2008); and pledge can be used in some cases where the previous types cannot (Borges, 1999). However, innovative MSMEs rarely have assets they can offer as collateral.

Likewise, the issue of fidejussory guarantees is also critical for MSMEs. Getting these guarantees can increase the costs for the credit borrower, and the guarantor may still require counter-guarantees to grant it. In addition, the enforcement of this type of guarantees can be slow (Borges, 1999). This set precludes this modality.

Our objective was to understand these different types of guarantee and their implications for accessing credit by knowledge-intensive MSMEs. The following section details the research steps and the methodological procedures associated to them.

\section{Methodological procedures}

The research approach is qualitative, and we carried it out in two steps. First, we identified and ranked the guarantees used by BRDE in its innovation financing operations, since the launching of BRDE Inova Program[1], in 2013, until the end of 2016. This survey was limited to the contracts signed under the programs Finep Inovacred and BNDES Innovative MSME, which are the refundable financing programs for innovation operated by BRDE specifically for MSMEs with annual revenues up to $\mathrm{R} \$ 90 \mathrm{~m}$. The period $2013-2016$ comprises all the closed financial years since 2013, until the writting of this paper, and includes the release of BNDES MSME Program, in 2014. At this stage, we used the documentary research for data collection by examining documents from BRDE's information system and the contracts signed with the companies.

In the second stage, we sought the perceptions of the players of the innovation ecosystem of the state of Santa Catarina regarding the adequacy of the program for knowledgeintensive MSMEs to finance their innovation projects, considering the types of guarantees adopted for their credit needs. Specifically, we examined: 
- strengths and limitations of the programs regarding the access to credit for innovation; and

- appropriateness of existing guarantee mechanisms.

To this end, we conducted semi-structured interviews with representatives of different companies and institutions relevant to the state's innovation ecosystem. We interviewed members of four institutions and two entrepreneurs with experience in these programs, as described in Table I.

Interviewees and their institutions/companies:

(1) Interviewee 1:

- Institution: Brazilian Association of Software Companies - Abes.

- Link: Director of Innovation and Promotion.

(2) Interviewee 2 :

- Institution: Reference Centers in Innovative Technologies - Certi Foundation.

- Link: Investment Analyst.

(3) Interviewee 3:

- Institution: Regional Bank for the Development of the Extreme South - BRDE.

- Link: Santa Catarina State Superintendent.

(4) Interviewee 4:

- Company: Chipus Microeletrônica S.A. (2008) - semiconductors.

- Link: Co-Founder Partner and CEO.

(5) Interviewee 5:

- Company: Ahgora Sistemas S.A. - management and control services based on cloud computing.

- Link: Partner and Director.

(6) Interviewee 6:

- Institution: Santa Catarina Association of Technology Companies - ACATE.

- Link: Executive Director.

We used descriptive and content analysis as methodological techniques. To strengthen the research findings, we used triangulated data collected in the different stages (Zappellini \& Feuerschütte, 2015).

\begin{tabular}{lccrrrrrrrr}
\hline & \multicolumn{2}{c}{2013} & \multicolumn{2}{c}{2014} & \multicolumn{2}{c}{2015} & \multicolumn{2}{c}{2016} & \multicolumn{2}{c}{ Total } \\
Program & $\mathrm{R} \$ \mathrm{~m}$ & $N$ & $\mathrm{R} \$ \mathrm{~m}$ & $N$ & $\mathrm{R} \$ \mathrm{~m}$ & $N$ & $\mathrm{R} \$ \mathrm{~m}$ & $N$ & $\mathrm{R} \$ \mathrm{~m}$ & $N$ \\
\hline Inovacred & 17.2 & 6 & 48.3 & 20 & 57.5 & 21 & 66.3 & 38 & 189.4 & 85 \\
Innovative MSME & - & 0 & 75.6 & 51 & 57.3 & 32 & 31.9 & 15 & 164.8 & 98 \\
Total & 17.2 & 6 & 123.9 & 71 & 114.9 & 53 & 98.2 & 53 & 354.2 & 183
\end{tabular}

Notes: ${ }^{\text {a }}$ The decrease in the number and value of operations in the BNDES Innovative MSME Program may relate to changes in interest rates, which raised from annual 4\% in 2014 to $6.5 \%$ in 2015 , and a variable rate in 2016 (BNDES, 2014, 2015, 2016), higher than in previous years

Source: Based on information from the BRDE CUBOS system

Table I.

BRDE Contracts under programs inovacred and innovative MSME between 2013 and 2016 
INMR

16,3

258

\section{Analysis and discussion of results}

4.1 Guarantees used by Regional Bank for the Development of the Extreme South in refundable financing of innovation

This section describes and analyzes the guarantees used by BRDE in credit operations under the programs Finep Inovacred and BNDES Innovative MSME, between 2013 and 2016. Table I presents the results of this survey.

Once identified the operations, we examined the types of guarantees in each contract. It was thus possible to determine the number and total value of the contracts that used each of the different types of guarantees. Figure 1 presents these results.

In general, the endorsement of partners or related companies is required in almost all funding operations and, therefore, it is the most used type of guarantee. Mortgage comes next, which shows the importance of real guarantees for getting credit, even in innovation projects. The guarantee programs operated by BRDE (BNDES FGI and Sebrae Fampe) are particularly relevant due to the special conditions set out by BRDE Inova, which commonly uses these programs in combination with other types of guarantees, or requirements that replace the guarantees. It is also worth noting that only one operation used the guarantee provided by a SGC, which shows the initial stage of this guarantee system.

The endorsement was the type of guarantee present in almost all contracts examined. It is an attribute of a credit title, in which the guarantor, through his/her signature, becomes co-responsible for the obligations of the borrower (Borges, 1999); hence, it is only valid for a credit title and never for another instrument (Fortuna, 2008). It is a full guarantee and represents solidarity (Casagrande, 2001; Fortuna, 2008). However, to achieve practical effects, both the guarantee and the endorsement require the guarantor to have moral repute and ability to pay, according to the transaction (Casagrande, 2001). As a disadvantage, there may be delay and insecurity regarding the procedural and legal rituals for the enforcement (Borges, 1999).

In the case of BRDE, it requires the endorsement of partners, controllers or company managers in most of the operations. In the BRDE Inova Program, under certain conditions, the endorsement of a third party with a privileged asset situation may be used, in addition to the guarantees provided by the endorsement programs.

In special situations, the endorsement can be waived, if it is difficult to grant fundings and there are other guarantees that make the operation safe. Our research identified that the

Figure 1.

Number and value of BRDE contracts in the specific innovation programs between 2013 and 2016 , by type of guarantee

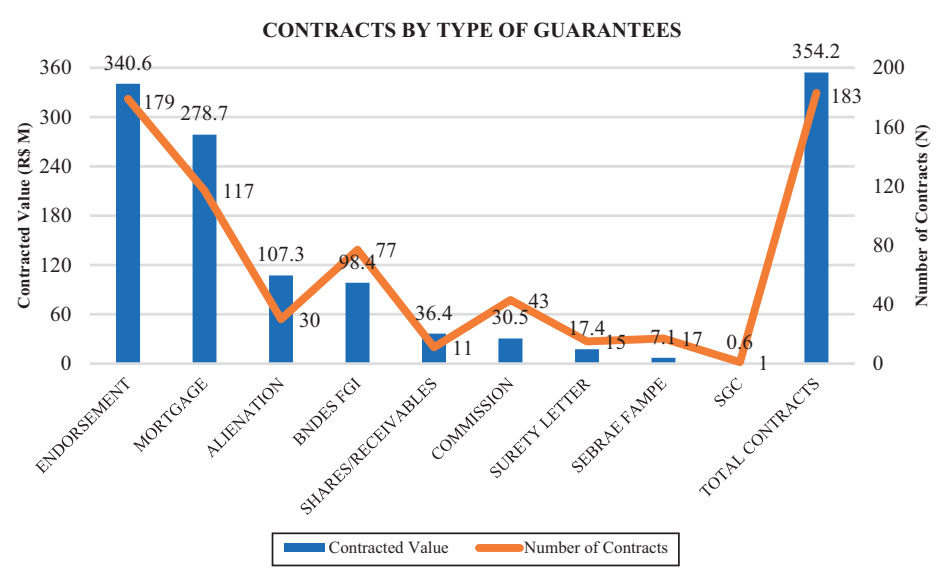


endorsement participated as a guarantee in 180 of the 183 contracts, according to the data presented in Table II.

Mortgage, on the other hand, is a type of guarantee that gives the creditor the privilege in the enforcement of a property, as well as incorporated buildings or movables (Borges, 1999). In case of non-payment of the debt, there may be judicial execution and the asset given as guarantee will go to judicial auction to pay the debt, excluding other creditors, who will only be entitled to the remains, if there is any (Canevari, 2013).

The mortgage's advantage is the possibility of "closed door" execution, which is the enforcement of a whole set comprised by the production unit property, including constructions and equipment necessary for the operation (Borges, 1999). Another benefit is the possibility of forming different mortgages of the same asset as collateral for different credit operations (Canevari, 2013).

As disadvantages, some authors mention the precarious situation of the Brazilian land registries (Borges, 1999), the preference for labor and tax creditors, and slowness of the Justice in the enforcement of guarantees (Borges, 1999; Fortuna, 2008). Although mortgage is still a very useful real guarantee for properties in the Brazilian legal system, it is increasingly weak nowadays (Canevari, 2013).

In the specific case of innovation financing in MSMEs by BRDE, mortgage was present in 117 operations, representing 63.9 per cent of the contracts, which amounted to $R \$ 278.7 \mathrm{~m}$ or 78.7 per cent of the volume financed, as shown in Table III:

These data show that the availability of some assets that can be mortgaged (or alienated) in favor of banks is still a relevant factor for getting refundable credit for innovation. This is true even for BRDE, which has a policy with special guarantee conditions for innovation financing - the BRDE Inova Program.

Although in many cases the program does not eliminate the demand for mortgage (or alienation), it enables a large reduction in the percentage of financing covered by such types of guarantees. Thus, a particular asset used as collateral can leverage larger volumes of funding.

Next, we address the credit guarantee programs used by BRDE - BNDES FGI and Sebrae Fampe. Together they are the third most relevant type of guarantee.

The guarantee programs try to overcome some of market imperfections by enabling creditors to transfer part of the financing risk to the guarantor entity. Therefore, they

\begin{tabular}{lrrrrr}
\hline & \multicolumn{2}{c}{ Value } & & No. & $\begin{array}{c}\text { Average value } \\
(\mathrm{R} \$ \mathrm{~m})\end{array}$ \\
Endorsement & $(\mathrm{R} \$ \mathrm{~m})$ & $(\%)$ & $(N)$ & $(\%)$ & 1.9 \\
Yes & 340.6 & 96.2 & 179 & 97.8 & 3.4 \\
No & 13.6 & 3.8 & 4 & 2.2 & 1.9 \\
Total & 354.2 & 100.0 & 183 & 100.0 & \\
\hline
\end{tabular}

Guarantees used in refundable financing

259

$-$

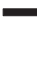

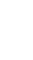


INMR

16,3

260

persuade creditors to grant credit to individuals or firms that otherwise would not be accepted as clients (Camino \& Cardone, 1999). They delegate the basic operation to financial entities, and the end user has no relationship with the program (Pombo \& Herrero, 2001).

Most of the modalities of BRDE Inova Program use one of the guarantee programs operated by BRDE, together with other types of guarantees or requirements that may replace the complementary guarantees, enabling the establishment of some operations without the provision of real guarantees.

Table IV shows the relevance of these programs in the composition of guarantees, regarding the programs Finep Inovacred and BNDES Innovative MSME.

Together, operations with guarantee programs represent 29.8 per cent of the transferred funds and 51.4 per cent of the contracts signed. The higher participation in the number of contracts than in the transferred amounts shows the importance of guarantee funds in the dissemination of credit for innovation, according to the operations' average value. In addition, Fampe is only used in operations with micro-firms. For this reason, the number of contracts and their average value are lower than those that used FGI.

The following is the fiduciary alienation, which guarantees the transfer of asset's ownership to the creditor during the financing term until its complete payment (Borges, 1999; Fortuna, 2008). More recently, alienation has been used for real estate purposes (Borges, 1999).

One of the advantages of fiduciary alienation is that there is no preference for privileged creditors, since the debtor no longer owns the alienated assets, even in the case of bankruptcy or composition (Borges, 1999; Canevari, 2013). In the event of non-payment, the process for guarantee enforcement is extrajudicial, faster than in the case of mortgage (Borges, 1999; Canevari, 2013; Fortuna, 2008). Through the alienation institute, credit operators count on an instrument of unprecedented efficiency and agility, which leads to greater safety in granting credit (Canevari, 2013). In contrast to mortgage, it is not possible to use the same alienated asset as collateral for other credit operations. Data regarding the use of this type of guarantee are presented in Table $\mathrm{V}$.

In general, the assets alienated in this type of operation are machines and equipment necessary to the innovation project. This situation is more common in innovation projects of the industrial sector, and the values are usually higher, as it can be seen by the average value of contracts through fiduciary alienation $(\mathrm{R} \$ 3.6 \mathrm{~m})$.

\begin{tabular}{|c|c|c|c|c|c|c|}
\hline & \multirow[b]{2}{*}{ Program (Guarantee funds) } & \multicolumn{2}{|c|}{ Value } & \multicolumn{2}{|c|}{ No. } & \multirow{2}{*}{$\begin{array}{l}\text { Average value } \\
\qquad(\mathrm{R} \$ \mathrm{~m})\end{array}$} \\
\hline & & $(\mathrm{R} \$ \mathrm{~m})$ & $(\%)$ & $(N)$ & $(\%)$ & \\
\hline & BNDES FGI & 98.4 & 27.8 & 77 & 42.1 & 1.3 \\
\hline Table IV. & Sebrae Fampe & 7.1 & 2.0 & 17 & 9.3 & 0.4 \\
\hline Use of guarantee & With program & 105.5 & 29.8 & 94 & 51.4 & 1.1 \\
\hline programs in the & Without program & 248.7 & 70.2 & 89 & 48.6 & 2.8 \\
\hline observed operations & Total & 354.2 & 100.0 & 183 & 100.0 & 1.9 \\
\hline
\end{tabular}

Table V.

Use of fiduciary alienation in the observed operations

\begin{tabular}{lccrrc}
\hline Fiduciary alienation & \multicolumn{2}{c}{ Value } & & No. & $\begin{array}{c}\text { Average value } \\
(\mathrm{R} \$ \mathrm{~m})\end{array}$ \\
\hline Yes & $(\mathrm{R} \$ \mathrm{~m})$ & $(\%)$ & $(N)$ & $(\%)$ & 3.6 \\
No & 107.2 & 30.3 & 30 & 16.4 & 1.6 \\
Total & 247 & 69.7 & 153 & 83.6 & 1.9 \\
\hline
\end{tabular}


Continuing with the most used guarantees, we gathered the fiduciary assignment of claims as collateral and the pledge of receivables or shares in the same group of guarantees for research purposes. Largely used in the Brazilian financial system, the fiduciary assignment of claims as collateral consists of the cession of credit rights to another person, as a payment method of an obligation (Casagrande, 2001). Credit operations guaranteed by receivables have been an alternative widely used in the financial system (Casagrande, 2001; Fortuna, 2008). They enable longer payment terms, cost reduction, portfolio diversification and a higher credit volume (Fortuna, 2008).

Pledge, on the other hand, is a right of privilege for the execution of an asset, and is described by a formalized written contract, although it does not require the public form (Borges, 1999). The contract may be a public or private instrument, or a ballot (Casagrande, 2001). There are several types of pledge:

- civil (delivery of the asset to the creditor);

- financial (formalized through credit notes);

- contractual (formalized through contracts);

- rural (directed to agricultural production);

- commercial (guarantees the commercial operation); and

- deposit (pledge of credit securities) (Casagrande, 2001).

Table VI shows these operations.

Representing 10.3 per cent of the volume financed, but only 6 per cent of the signed contracts, the pledge of shares and receivables does not have a significant participation in the number of contracted operations. However, the high average value of operations stands out, suggesting that these types of guarantees are used in operations with more developed companies.

Although not properly a type of guarantee, the so-called tariff for guarantees structuring (TEC) is a way to guarantee the flexibilization provided by the BRDE Inova Program. It complements the guarantee programs to enable financing for innovative MSMEs that do not possess other types of guarantees. Table VII presents data on its use.

Generally, this mechanism is offered to companies that have no access to another type of guarantee and, consequently, would not have access to credit for innovation. Although there is a cost for using such mechanism, it enabled the refundable financing of 43 companies. We highlight the low average value of operations $(\mathrm{R} \$ 0.7 \mathrm{~m})$, which confirms the importance of this instrument for innovative MSMEs.

In contrast, the guarantee is an autonomous contract in which the guarantor ensures the payment of a debtor's obligation, in case he/she cannot pay off his/her debts (Borges, 1999; Casagrande, 2001; Zica \& Martins, 2008). It is an ancillary obligation of a main duty, i.e. an ancillary contract that guarantees the compliance of another contract's obligations (Borges, 1999; Casagrande, 2001; Fortuna, 2008). In general, financial institutions provide the bank

\begin{tabular}{lrrrrc}
\hline & \multicolumn{2}{c}{ Value } & & No. & $\begin{array}{c}\text { Average value } \\
(\mathrm{R} \$ \mathrm{~m})\end{array}$ \\
Shares/receivables & $(\mathrm{R} \$ \mathrm{~m})$ & $(\%)$ & $(N)$ & $(\%)$ & 3.3 \\
\hline Yes & 36.4 & 10.3 & 11 & 6.0 & 1.8 \\
No & 317.8 & 89.7 & 172 & 94.0 & 1.9 \\
Total & 354.2 & 100.0 & 183 & 100.0 & \\
\hline
\end{tabular}

Guarantees used in refundable financing

261

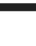


INMR

16,3

262

Table VII.

Use of TEC in the observed operations guarantee (or surety letter) to their best clients to enable them to access credit lines of other banks (Fortuna, 2008). Often, bank guarantees are valid for one year or less and must be annually renewed, which can generate costs for companies and become a barrier for longterm operations.

Table VIII shows the number of operations that used surety letter in the composition of guarantees.

The small number of transactions with surety letter seems to be related to its high cost. The low average value of the operations may indicate that it is an instrument used by smaller companies, precisely because they do not have access to other types of guarantees.

Finally, societies for credit guarantee (SGC) are, in general terms, private companies whose purpose is to complement the guarantees required by their members in credit operations (Sebrae, 2009).

Unlike guarantee programs, SGCs have the advantage of dealing with public and private resources, which results in some co-responsibility for the credit guarantee to the borrower (Santos, 2006). Their local relationships and the individuals' concern to watch over their names or reputation are excellent substitutes for the asset securities and counterparts (Carvalho \& Abramovay, 2004). This enables the reduction of the moral risk of operations because of the mutual character of these institutions and the implicit peer pressure (Santos, 2006). Finally, SGCs participate in the credit analysis (Mello \& Schossland, 2015; Pombo \& Herrero, 2001; Santos, 2006), and they decide to grant or not the guarantee (Santos, 2006).

In the case of BRDE, regarding its credit operations to finance innovation in MSMEs, there was only one contract that got the guarantee provided by a SGC.

Although SGCs are solid and relevant institutions in other countries, they are very recent in Brazil. Understanding why they are still not consolidated locally, with a more widespread instrument of complementary guarantees, can be a rich field of research (Table IX).

\subsection{Perceptions of the players of the innovation ecosystem of the state of Santa Catarina on} the problems of real guarantees for innovation financing

In this section, we analyze the interviews conducted herein to check the perception of the research subjects on the strengths and limitations of the programs, regarding access to credit for innovation, and the adequacy of the existing guarantee mechanisms.

\begin{tabular}{lrrrrr}
\hline & & Value & & No. & $\begin{array}{c}\text { Average value } \\
(\mathrm{R} \$ \mathrm{~m})\end{array}$ \\
TEC & $(\mathrm{R} \$ \mathrm{~m})$ & \multicolumn{1}{c}{$(\mathrm{N})$} & $(N)$ & $(\%)$ & 0.7 \\
Yes & 30.5 & 8.6 & 43 & 23.5 & 2.3 \\
No & 323.7 & 91.4 & 140 & 76.5 & 1.9 \\
Total & 354.2 & 100.0 & 183 & 100.0 &
\end{tabular}

\begin{tabular}{|c|c|c|c|c|c|c|}
\hline \multirow{5}{*}{$\begin{array}{l}\text { Table VIII. } \\
\text { Use of surety letter in } \\
\text { the observed } \\
\text { operations }\end{array}$} & & \multicolumn{2}{|c|}{ Value } & \multicolumn{2}{|c|}{ No. } & \multirow{2}{*}{$\begin{array}{l}\text { Average value } \\
\qquad(\mathrm{R} \$ \mathrm{~m})\end{array}$} \\
\hline & Surety letter & $(\mathrm{R} \$ \mathrm{~m})$ & $(\%)$ & $(N)$ & $(\%)$ & \\
\hline & Yes & 17.4 & 4.9 & 15 & 8.2 & 1.2 \\
\hline & No & 336.8 & 95.1 & 168 & 91.8 & 2.0 \\
\hline & Total & 354.2 & 100.0 & 183 & 100.0 & 1.9 \\
\hline
\end{tabular}


The strengths most cited by the interviewees were the programs' terms and the subsidized interest rates. Interviewee 5 praised the funded items, which include important elements that are unusual in other programs. Among these items are own workforce and expenses for traveling and consulting.

Interviewee 1 considered the programs' decentralization positive, with the resources passed on by regional partners, which enables the capillarity of resource distribution. For him, the proximity between banks and entrepreneurs can make credit analysis more efficient, reduce non-payment, simplify processes and loosen guarantees. In the same line, INTERVIEWEE 4 stated that things would be more complex and slower if his firm had to deal directly with BNDES or Finep. The players of the innovation ecosystem of Santa Catarina highlighted the funded items and decentralization as strengths of the economic subsidy program, as mentioned by Borges and Hoffmann (2017).

Interviewees 1, 4 and 5 agreed that financial products for innovation should be simple and fast because in general there is no need for big resources to develop an idea; but delay in releasing them may result in the loss of an opportunity. For Interviewee 1, the entrepreneur is willing to pay for the credit, but expects agility and safety in the process. He exemplified his argument by saying that the Product "BNDES Card" was successful due to its convenience, in addition to the low demand for guarantees and counterparts (Bueno \& Torkomian, 2015).

Interviewee 1 also highlighted the continuous flow of these programs. When the selection occurs through public calls, there is a high cost involved and human resource overload, from the public notice to the proposal's selection. Thus, companies' need for speed can also make this model unfeasible (Gonçalves, Mello \& Torres, 2015).

At this research stage, we investigated the limits of the programs perceived by the interviewees. The most mentioned were the excess of bureaucracy, process delay, lack of guarantees, lack of communication and understanding of the programs, legal uncertainty, lack of qualification of some entrepreneurs, specificities of technology companies, difficulty in designing projects, and relatively high cost of operations with MSMEs. According to theory, the lack of guarantees and the relatively high cost of operations are the main causes of credit shortage faced by smaller companies (Baumgartner \& Casarotto Filho, 2001; Nicolae \& Daniel, 2011; Pombo \& Herrero, 2001; Santos, 2006; Stiglitz \& Weiss, 1981; Zica \& Martins, 2008).

Literature presents different definitions of innovation, and the Oslo Manual (OECD, 2005) is the benchmark used by financial institutions. However, Interviewees 1, 3 and 5 observed that defining the innovative merit of projects is a very subjective task. According to Interviewee 1 , banks are insecure to consider a particular project as innovative, and often deny credit. Thus, Interviewees 1,2 , and 5 suggested that other innovation financing programs adopt objective criteria to determine whether a project or company qualifies as innovative. Silva (2016) investigated this topic and suggested innovation criteria to support the selection of projects for the Inovacred Program. In addition, Interviewees 1, 2 and 5 considered essential for banks to know better the most innovative segments. In its

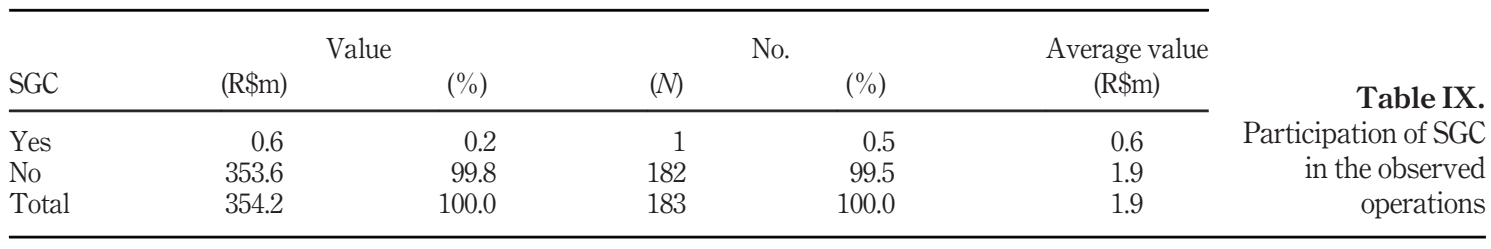

Guarantees used in refundable financing

263

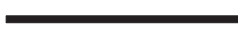


INMR

16,3

264

conception, BRDE Inova sought to fill this gap by approaching institutions with expertise in the field of innovation through operational agreements, where partner institutions could assist the bank in assessing the innovative merit of projects. The Research Foundations (FAPs) are an example of this type of institution, focused on the financing of ST\&I projects.

Another obstacle mentioned by Interviewee 1, and highlighted by Baumgartner and Casarotto Filho (2001), and Santos (2006), regards the relatively high operational costs of financing MSMEs. From their perspective, operational costs of a small operation are practically the same as a large one, which encumbers smaller companies.

Proceeding to the analysis of the adequacy of the guarantees used in the program, Interviewees 2 and 4 emphasized the high cost of some types of guarantees, such as surety letters. In addition, their terms are up to one year, which requires annual renewals for longterm operations.

Interviewee 4 explained that in knowledge-intensive companies, such as the one where he is the CEO, it is impossible to make assets tangible for using as collateral. The entrepreneur recalled when he applied for credit at BRDE, and they considered the bank getting an equity stake in the company as a guarantee for the funding. At the time, the firm was in an early stage and negotiation did not evolve. Thus, as explained by Schumpeter (1982), the current system acts as an ex-ante selection mechanism, i.e. it already aborts innovation in the project stage. INTERVIEWEE 5 agreed, and said, "By improving the issue of guarantees, maybe the virtual barrier for getting credit for innovation decreases."

In Brazil, there are guarantee programs that aim to minimize credit barriers. BRDE currently operates with BNDES FGI and Sebrae Fampe. Among the criticisms found in literature, one may find the bureaucracy involved in the analysis, the lack of instruments, and the high endorsement rates, besides the requirement of additional guarantees (Baumgartner \& Casarotto Filho, 2001). For Interviewees 1 and 2, a major obstacle to FGI and Fampe was the limit of the guarantee percentage to 80 per cent of the amount funded. "The lack of complementarity makes new operations unfeasible," emphasized Interviewee 2. "Although there are good mechanisms and ideas, something is lacking to cover a gap in the stage of firms' growth."

In an overall review of the adequacy of existing instruments, Interviewee 6 observed that innovation investments involve risks that must be assigned to creditors. Given the nature of these projects, failure is a possibility; therefore, it is necessary to create new instruments to spread the risks. Interviewee 3 observed that little progress has been made on the issue of guarantees, despite the advances of the financial system. Hence, alternative guarantee instruments are essential, so that these investments are not reduced. Table X summarizes the main findings of the interviews.

In short, for the specific reality of knowledge-intensive MSMEs, among the identified limits, one can mention the difficulty of establishing tangible assets to be used as collateral

Table X.

Synthesis of interviewees' perception on the programs and guarantee mechanisms

\begin{tabular}{lll}
\hline Programs' strengths & Programs' limitations & Adequacy of guarantees \\
\hline Terms & Excess of bureaucracy & High cost \\
Subsidized interest & Slowness & Term - need for annual renewals \\
Funded items & Lack of communication & Lack of guarantees \\
Decentralization & Difficulty of understanding/Lack & Difficulty to make assets tangible \\
Continuous flow & $\begin{array}{l}\text { of qualification of entrepreneurs } \\
\text { Difficulty to design projects }\end{array}$ & \\
& Subjectivity in defining the & \\
& innovative character of the project & \\
& Legal uncertainty & \\
\hline
\end{tabular}


(ABES, 2016; Garcia-Tabuenca \& Crespo-Espert, 2010). Therefore, although the program has brought possibilities of differential guarantees, there are still limitations associated with the prevalence of traditional modalities.

\section{Final remarks}

Although the Brazilian National Innovation System comprises specific programs for refundable financing of innovation, MSMEs still face difficulties to access these resources. The lack of required guarantees is one of the main barriers.

By enabling differential guarantee conditions, BRDE Inova Program contributed to the bank becoming the national leader in the transfer of Inovacred and Innovative MPME programs. Despite the advances, the analysis of funded projects showed that the availability of assets for mortgage or alienation is a significant factor in getting credit for innovation projects of MSMEs, which is a particularly relevant limit for knowledge-intensive companies. Therefore, the guarantee mechanisms available do not fit these companies' needs. Interviews with entrepreneurs of knowledge-intensive sectors and managers of institutions in innovation ecosystem of the Santa Catarina showed that such restriction remains.

Besides being a limitation for individual companies, such scenario creates a barrier to the advancement of the National System of ST\&I, whose financing mechanisms have structural problems. The Good Law, which grants tax incentives to companies that invest in Research and Development (R\&D), still does not meet the needs of MSMEs accounting. Resources for nonrefundable financing suffer with the decrease of the public budget for innovation and, as we saw, credit still imposes barriers mainly to knowledge-intensive companies, which are precisely those that belong to relevant sectors that can change the Brazilian production structure.

Hence, the study shows elements that can contribute to the advancement of financing policies of both BRDE and other financial agents of the National Innovation System. Regarding theoretical implications, it helps to fill the existing gap in the national literature related to the guarantee systems for innovation credit applied to the reality of knowledge-intensive MSMEs. In addition, it focuses on a level of analysis not explored in other studies: the project level. By examining individually the contracted projects, it was possible to draw very specific conclusions about the guarantee mechanisms effectively adopted in that program.

In conclusion, we emphasize the relevance of developing Credit Guarantee Companies to advance in this field. SGCs are solid institutions in other countries, but still very incipient in Brazil. We finish by suggesting future studies to understand why SGCs have not yet consolidated in the country as an instrument for providing complementary guarantees.

\section{Note}

1. Finep and BNDES programs relate to refundable resources passed on by accredited financial institutions, while the BRDE Inova Program is a policy for stimulating innovation that, among other things, enables a differential treatment regarding the guarantees required for innovative companies and projects.

\section{References}

Araújo, J. O. (2014). Sistema de garantias e seguros: Uma ferramenta de ampla cobertura funcional [Guarantee and insurance system: A tool with wide functional coverage]. Associação brasileira de desenvolvimento. Prêmio ABDE: Melhores práticas do sistema nacional de fomento Coletânea de trabalhos. Rio De Janeiro, Brazil: ABDE editorial.

\section{Guarantees used in refundable financing}

265 
INMR 16,3

Associação Brasileira das Empresas de Software (ABES). (2016). Pesquisa ABES de acesso a financiamento [ABES research on access to financing]. Retrieved from www.abessoftware.com.br/ servicos/estudos-pesquisas-e-pareceres

Banco Nacional de Desenvolvimento Econômico e Social. (2014). Circular SUP/AOI no. 06/2014. Programa BNDES de apoio à Micro, Pequena e média empresa inovadora - BNDES MPME inovadora [Circular letter SUP/AOI no. 06/2014. BNDES program to support micro, small and medium-sized enterprises - BNDES innovative MSME]. Rio de Janeiro, Brazil: BNDES, Retrieved from www.bndes.gov.br/wps/portal/site/home/instituicoes-financeiras-credenciadas/ normas/normas-operacoes-indiretas/

Banco Nacional de Desenvolvimento Econômico e Social. (2015). Circular SUP/AOI no. 07/2015. Programa BNDES de apoio à Micro, Pequena e média empresa inovadora - BNDES MPME inovadora [Circular letter SUP/AOI no. 07/2015. BNDES program to support micro, small and medium-sized enterprises - BNDES innovative MSME]. Rio de Janeiro, Brazil: BNDES. Retrieved from www.bndes.gov.br/wps/portal/site/home/instituicoes-financeiras-credenciadas/ normas/normas-operacoes-indiretas/

Banco Nacional de Desenvolvimento Econômico e Social. (2016). Circular SUP/AOI no. 06/2016. Programa BNDES de apoio à micro, pequena e média empresa inovadora - BNDES MPME inovadora [Circular letter SUP/AOI no. 06/2014. BNDES program to support micro, small and medium-sized enterprises - BNDES innovative MSME]. Rio de Janeiro, Brazil: BNDES. Retrieved from www.bndes.gov.br/wps/portal/site/home/instituicoes-financeiras-credenciadas/ normas/normas-operacoes-indiretas/

Baumgartner, R., \& Casarotto Filho, N. (2001). Sistema de concessão de crédito às micro e pequenas empresas no brasil a partir da experiência italiana. Anais do II encontro de estudos sobre empreendedorismo e gestão de pequenas empresas [EGEPE] [Credit granting system for micro and small enterprises companies in Brazil from the Italian experience. Annals of the II study meeting on entrepreneurship and small business management [EGEP]]. Londrina, PR, pp. 539-550.

Borges, L. F. X. (1999). Covenants: Instrumento de garantia em project finance [Convenants: Instrument of guarantee in project finance]. Revista Do BNDES, 6, 1-24. Retrieved from

Borges, D. B. \& Hoffmann, M. G. (2017). A subvenção econômica como instrumento de fomento à inovação: Análise sob a perspectiva de empresas de TIC da grande florianópolis. Revista Brasileira de Gestão e Inovação, 5, 50-73. http://dx.doi.org/10.18226/23190639.v5n1.03

Buainain, A. M., Lima, I. S. Jr., \& Corder, S. (2017). Desafios do financiamento à inovação no Brasil [Challenges of financing innovation in Brazil]. In D. R., Coutinho, M. C., Foss, \& P. S. B., Mouallem (Eds), Inovação no brasil. Avanços e desafios jurídicos e institucionais. São Paulo, Brazil: Blucher.

Bueno, A. \& Torkomian, A. L. V. (2015). Financiamentos à inovação tecnológica: Reembolsáveis, não reembolsáveis e incentivos fiscais [Financing technological innovation: Refundable, non refundable and tax incentives]. Review of Administration and Innovation - Rai, 11, 135-158.

Camino, D. \& Cardone, C. (1999). The valuation and cost of credit insurance schemes for SMEs: The role of the loan guarantee associations. International Small Business Journal: Researching Entrepreneurship, 17, 13-31.

Canevari, R. Q. (2013). Considerações acerca dos direitos reais de garantia imobiliária: Alienação fiduciária $\mathrm{x}$ hipoteca [Considerations about the real rights of property collateral: fiduciary alienation vs mortgage]. Ámbito Jurídico, 16. Retrieved from www.ambitojuridico.com.br/site/? n_link=revista_artigos_leitura\&artigo_id $=13467$

Carvalho, C. E. \& Abramovay, R. (2004), O difícil e custoso acesso ao sistema financeiro [The difficult and costly access to the financial system]. In C.A., Santos (Eds.), Sistema financeiro e as micro e pequenas empresas: Diagnósticos e perspectivas (pp. 17-45), 2a ed., Brasília, Brazil: Sebrae.

Casagrande, Z.J. (2001). Proposta de Sociedade Local de Garantia Para Micro e Pequenas Empresas [Proposal for Local Guarantee Society for Micro and Small Enterprises]. (Dissertação de 
Mestrado). Programa de Pós-Graduação em Engenharia de Produção, Universidade Federal de Santa Catarina, Florianópolis, SC.

Corder, S. \& Salles Filho, S. (2009). Aspectos conceituais do financiamento à inovação [Conceptual aspects of innovation financing]. Revista Brasileira de Inovação, 5, 33-76. https://doi.org/10 .20396/rbi.v5i1.8648923

Fortuna, E. (2008). Mercado financeiro: Produtos e serviços [Financial markets: Products and services], 17a ed., Rio de Janeiro, Brazil: Qualitymark.

Garcia-Tabuenca, A. \& Crespo-Espert, J. (2010). Credit guarantees and SME efficiency. Small Business Economics, 35, 113-128.

Gonçalves, L. R., Mello, A. M., Torres, A. S. Jr (2015). Composição de carteira de projetos de P\&D com recursos públicos: Dificuldades e soluções [Composition of R\&D project portfolio with public resources: Difficulties and solutions]. RAI - Revista de Administração e Inovação, 12, 238-256.

Instituto Brasileiro de Geografia e Estatística (IBGE). (2013). PINTEC: Pesquisa de inovação 2011 [2011 Innovation survey], Rio de Janeiro, Brazil: IBGE.

Jang, W. \& Chang, W. (2008). The impact of financial support system on technology innovation: A case of technology guarantee system in Korea. Journal of Technology Management and Innovation, 3 , 10-16. Reprieved from

Luo, P., Wang, H., \& Yang, Z. (2016). Investment and financing for SMEs with a partial guarantee and jump risk. European Journal of Operational Research, 249, 1161-1168, https://doi. org/10.1016/j .ejor.2015.09.032.

Mello, R. A. \& Schossland, S. (2015). Sociedade de garantia solidária: alternativa eficaz de acesso ao crédito Para micro e pequenas empresas [Solidarity guarantee society: An effective alternative of credit access to the micro and small enterprises], Joinville, Brazil: Editora Letradágua.

Nicolae, P. \& Daniel, B. (2011). Collateral's importance in SMEs financing: What is the banks response? Some evidence for Romania. Annals of the University of Oradea, 20, 256-260. Economic Science Series,

Organization for Economic Co-operation and Development (OECD). (2005). Manual de Oslo-Diretrizes para coleta e interpretação de dados sobre inovação [Oslo Manual - Guidelines for data collection and interpretation on innovation], 3a ed., Brasília, Brazil: OECD/Eurostat/Finep.

Organization for Economic Co-operation and Development (OECD). (2006). The SME financing gap: Theory and evidence, Paris, France: OECD Publishing. https://doi.org/10.1787/9789264029415-en

Pombo, P. \& Herrero, A. (2001). Los sistemas de garantías Para la micro y la pyme en una economia globalizada [The guarantee systems for micro and SME in an globalized economy], Sevilla, Spain: DP Editorial.

Sabatini-Marques, J. S., Yigitcanlar, T., \& Costa, E.M. (2015). Australian innovation ecosystem: A critical review of the national innovation support mechanisms. Asia Pacific Journal of Innovation and Entrepreneurship, 9, 3-28. Retrieved from https://eprints.qut.edu.au/91574/

Santos, C.A. (2006). Risco de crédito e garantias: A proposta de um sistema nacional de garantias [Credit risk and guarantees: The proposal for a national guarantee system], Brasília, Brazil: SEBRAE.

Schumpeter, J. A. (1982). Teoria do desenvolvimento econômico: Uma investigação sobre lucros, capital, crédito, juro e o ciclo econômico [The theory of economic development: An inquiry into profits, capital, credit, interest, and the business cycle], São Paulo, Brazil: Abril Cultural.

Serviço Brasileiro de Apoio às Micro e Pequenas Empresas (Sebrae). (2009). Sociedade garantidora de crédito [Credit guarantee society]. Série empreendimento coletivos, Brasília, Brazil: Sebrae.

Serviço Brasileiro de Apoio às Micro e Pequenas Empresas de São Paulo (Sebrae-SP). (2006). Sondagem de opinião: financiamento de micro e pequenas empresas (MPE) no estado de são paulo [Opinion polling: Micro and small business (MPE) financing in the state of são paulo], São Paulo, Brazil: Sebrae-SP.

Silva, M. M. (2016). Proposta de critérios de inovação Para auxiliar no processo de seleção de projetos do programa inovacred [Proposal of innovation criteria to assist in the process of selection of 
INMR

16,3

inovacred program projects]. (Dissertação de Mestrado), Universidade Federal do Paraná, Curitiba.

Stiglitz, J. E. \& Weiss, A. (1981). Credit rationing in markets with imperfect information. The American Economic Review, 71, 393-410. Retrieved from https://econpapers.repec.org/article/aeaaecrev/ v_3a71_3ay_3a1981_3ai_3a3_3ap_3a393-410.htm

Zappellini, M. B. \& Feuerschütte, S. G. (2015). O uso da triangulação na pesquisa científica brasileira em administração [The use of triangulation in Brazilian scientific research in administration: Education and research]. Administração: Ensino e Pesquisa, 16, 241-273, http://dx. doi.org/10. 13058/raep.2015.v16n2.238.

Zen, A. C. \& Fracasso, E. M. (2012). Recursos, competências e capacidade de inovação: Um estudo de múltiplos casos na indústria eletroeletrônica no Rio Grande Do Sul [Resources, skills and capacity for innovation: A study of multiple cases in the electronics industry in Rio Grande do Sul]. RAI - Revista de Administração e Inovação, 9, 177-201. http://dx.doi.org/10.5773/rai.v9i4. 877.

Zica, R. M. F. \& Martins, H. C. (2008). Sistema de garantia de crédito Para micro e pequenas empresas no brasil: Proposta de um modelo [Credit Guarantee System for Micro and Small Businesses in Brazil: Proposal of a model]. Revista de Administração Pública, 42, 181-204. http://dx.doi.org/10. 1590/S0034-76122008000100009.

\section{Corresponding author}

Richard Cunha Schmidt can be contacted at: richard.schmidt@hotmail.com

Associate editor: Felipe Mendes Borini

For instructions on how to order reprints of this article, please visit our website: www.emeraldgrouppublishing.com/licensing/reprints.htm Or contact us for further details: permissions@emeraldinsight.com 